Original Research Paper

\title{
Investigation of Chlorophyll-an in a Small Reservoir by Landsat 7 Imagery
}

\author{
${ }^{1}$ Maryam Ghashghaie, ${ }^{2}$ Kaveh Ostad-Ali-Askari and ${ }^{3}$ Saeid Eslamian \\ ${ }^{I}$ Department of Water Resources Engineering, \\ Faculty of Agriculture, Bu-Ali Sina University, Hamedan, 6517833131, Iran \\ ${ }^{2}$ Department of Civil Engineering, Isfahan (Khorasgan) Branch, Islamic Azad University, Isfahan, Iran \\ ${ }^{3}$ Department of Water Engineering, Isfahan University of Technology, Isfahan, Iran
}

Article history

Received: 28-02-2018

Revised: 02-04-2018

Accepted: 20-04-2018

Corresponding Author:

Kaveh Ostad-Ali-Askari

Department of Civil

Engineering, Isfahan

(Khorasgan) Branch, Islamic

Azad University, Isfahan, Iran

Email: koa.askari@khuisf.ac.ir

\begin{abstract}
Chlorophyll-a (chla) is a source of water pollution. Monitoring the quality of water in reservoirs is necessary to take any action for protecting the water quality. Traditional methods of sampling are usually costly and time consuming. Also they need skillful labors and some areas are out of reach or sampling at those areas is dangerous. Remote sensing technology could solve problems of high cost, time consuming and unavailability of traditional sampling methods. Landsat 7 imagery is a suitable resource of data because it has been using since a long time ago and could be used to analyze past events. This research aims to investigate the possibility of eutrophication assessment in Ecbatan reservoir using remote sensing images. Field data of the study such as chla were collected in 2010. To reach this aim first the Top of Atmosphere (TOA) reflectance of imagery was calculated for each band. Then the relationship between concentration of chla and reflectance values was determined. Different conversions were applied on reflectance values at the next step to find the best regression equation for estimating the concentration of chla. The best model for estimating the concentration of chla was based on the band ratios. The values of $R_{A d j}^{2}$ and SE are 0.91 and 0.04 respectively for this model. Based on the results of this research Landsat 7 is capable of reflecting the eutrophication problem in a small reservoir as Ecbatan.
\end{abstract}

Keywords: Chlorophyll-a, Reflectance, Remote Sensing, Small Reservoir, Water Pollution

\section{Introduction}

High concentration of nutrients in drained water from different land uses such as agriculture, rural and urban areas intensifies the growth of algae in water bodies such as lakes and reservoirs. Consequently, the water quality in lakes and reservoirs decreases. Algal blooms cause eutrophication in water bodies. As a result, the dissolved oxygen is declined in these systems. This problem causes the death of aquatic creatures and fishes. Also algae growth decreases water opacity and produces a kind of poison which is harmful both for human and fishes. Industrial and aesthetics use of water is restricted and affected by eutrophication and algal blooms.

In recent years the amount and frequency of algal blooms has increased in coastal areas and inland waters (case 2) (Jin et al., 2005; Smith and Schindler, 2009). As a whole the main problem caused by eutrophication is supposed to be algae production that is annoying and troublesome for the public (Smith, 2003).

Eutrophication and water quality decline has negative industrial impacts that receives attention in different countries ( $\mathrm{Yu}$ et al., 2011). Reservoirs are usually located at the outlet of the basins. Controlling the quality of water in upstream is easier and more economic in comparison with purifying and improving it in downstream of a reservoir. To reach this aim it is necessary to inform managers from the statue of water quality before it becomes too late to take any action in order to save the clean water. Field measurements to examine the quality of water behind the dams, are usually very time consuming and expensive. A skillful labor is required for field sampling. Also reservoirs are very dangerous due to a high amount of sediment and high depth near the dam structure. Consequently, a system is required to inform the managers and operators 
about the statue of water quality in reservoir that is independent from field measurements. This system acts as a pre-informative and warning tool.

Remote sensing images can help scientists to complete their information about water components and its statues. Investigating the eutrophication and its short and long term variations in coastal areas and lakes is possible using satellite imagery. Managerial strategies could be used to control and protect the quality of water in reservoirs.

Most of the algal blooms are detectable by multispectral sensors since their colors are different (Ruddick et al., 2001). The concentration of chla is a keyfactor in water quality studies (Schalles et al., 1998; Honeywill et al., 2002) and it is very important in determining the degree of eutrophication in a water body. Different studies have been accomplished on eutrophication using various approaches (Jarvie et al., 2006; Kuo et al., 2007; Smith and Schindler, 2009). Many studies also have examined the capability of remote sensing imagery in estimating the concentration of chla (Zhang et al., 2015). Some of these studies focus on coastal areas and seas. They use satellite images with high frequencies such as MODIS. However, the spatial resolution of such imagery are usually low and vary between 250 and $1000 \mathrm{~m}$ which is not convenient for small lakes.

Researchers such as Carder et al. (2004) investigated the capability of MODIS imagery to estimate chla in several coastal areas in USA. Also Vincent et al. (2004) extracted several algorithms to estimate the number of Phycosyanin cells and the value of turbidity in Lake Erie using Landsat 7 and Landsat 5 imagery. They used bands one, two, three, four and five for the phycocyanin model and logarithm of band two to band three ratio for the chla model.

Different studies were accomplished using MODIS and SeaWiFS to estimate the concentration of chla in central area of west Florida coast such as Carvalho et al. (2007). MERIS imagery were used to estimate the concentration of chla and phycocyanin (Wheeler et al., 2012). They extracted a model for chla and phycocyanin in Missisquoi bay and Lake Champlain. Also Waxter (2014) analyzed and investigated the capability of remote sensing images to discover and monitor the algal blooms in Tenmile lakes in Oregan coasts. They used Landsat 5 images with \pm 3 day time difference.

Trescott et al. (2013) proposed a model to estimate the quality of water in Lake Champlain using Landsat 7 imagery. This study showed that bands one, two and three have a good correlation with the number of cyanobacteria cells. Also Isenstein et al. (2014) proposed chla algorithms using Landsat 7 imagery to estimates the amount of Phycocyanin and Cyanobacteria. They proved that band two shows a good correlation with chla concentration. Tayebi and Sarajian (2013) studied eutrophication problem in Persian Gulf. They investigated the red tie phenomenon of Persian Gulf in 2011. A time series of Landsat-MSS/TM/OLI from 1973 to 2013 to was used to monitor the effects of a mine activity on Tapajos River (Lobo et al., 2015).

Satellite images with a high spatial resolution such as Landsat 7 are more convenient for reservoirs since their area is much smaller than seas and coastal areas. The components of water such as chla could be estimated using Landsat 7 imagery. Although the application of these images are limited to every 16 days. This imagery is suitable for investigating the quality of such resources as they have higher spatial resolution. Besides these images are free and available to public.

Since the time of water stability in a reservoir and lake is high enough, suspended sediments, nutrients and phytoplankton is accumulated in the environment. As a result, visual and optical characteristics of water becomes more complicated (Darecki and Stramski, 2004; Dall'Olmo et al., 2005). This may cause errors in estimating the parameters accurately. The best combination of bands are mainly used to estimate the water quality parameter. Different algorithms have been developed using red and infrared reflectance to estimate the concentration of chla more accurately (Ruddick et al., 2001; Dall'Olmo et al., 2005; Moses et al., 2009a; 2009b; Yang et al., 2010; Gurlin et al., 2011; Gitelson et al., 2011). Parameters of these algorithms could be determined by comparing the data from imagery and field data of a specified study area. The aim of this study is to investigate the capability of Landsat 7 imagery for estimating the concentration of chla in Ecbatan reservoir and extracting the best model for this purpose.

\section{Methodology}

\section{The Study Area}

Hamedan is a mountainous city located in west of Iran. It is the capital of Hamedan province. Abshine River originates from Alvand Mountains and inflows through Ecbatan Lake. Ecbatan dam is located in south west of Hamedan city on Abshine River in $34^{\circ} 45^{\prime} 24^{\prime \prime} \mathrm{N}$ and $48^{\circ} 36^{\prime} 10^{\prime \prime} \mathrm{E}$. The area of the lake at normal level is $1.75 \mathrm{Km}^{2}$. Figure. 1 shows the location of Ecbatan Dam.

This dam was first built to supply drinking and agriculture water demand for Hamedan city in 1963. The height of this dam was increased to $79 \mathrm{~m}$ in 2008 . Ecbatan reservoir is a resource of fresh water used for Hamedan city. The reservoir has shown eutrophic symptoms in recent years (Norouzi et al., 2011). The concentration of nutrients is relatively high in this reservoir (Samarghandi et al., 2013). 


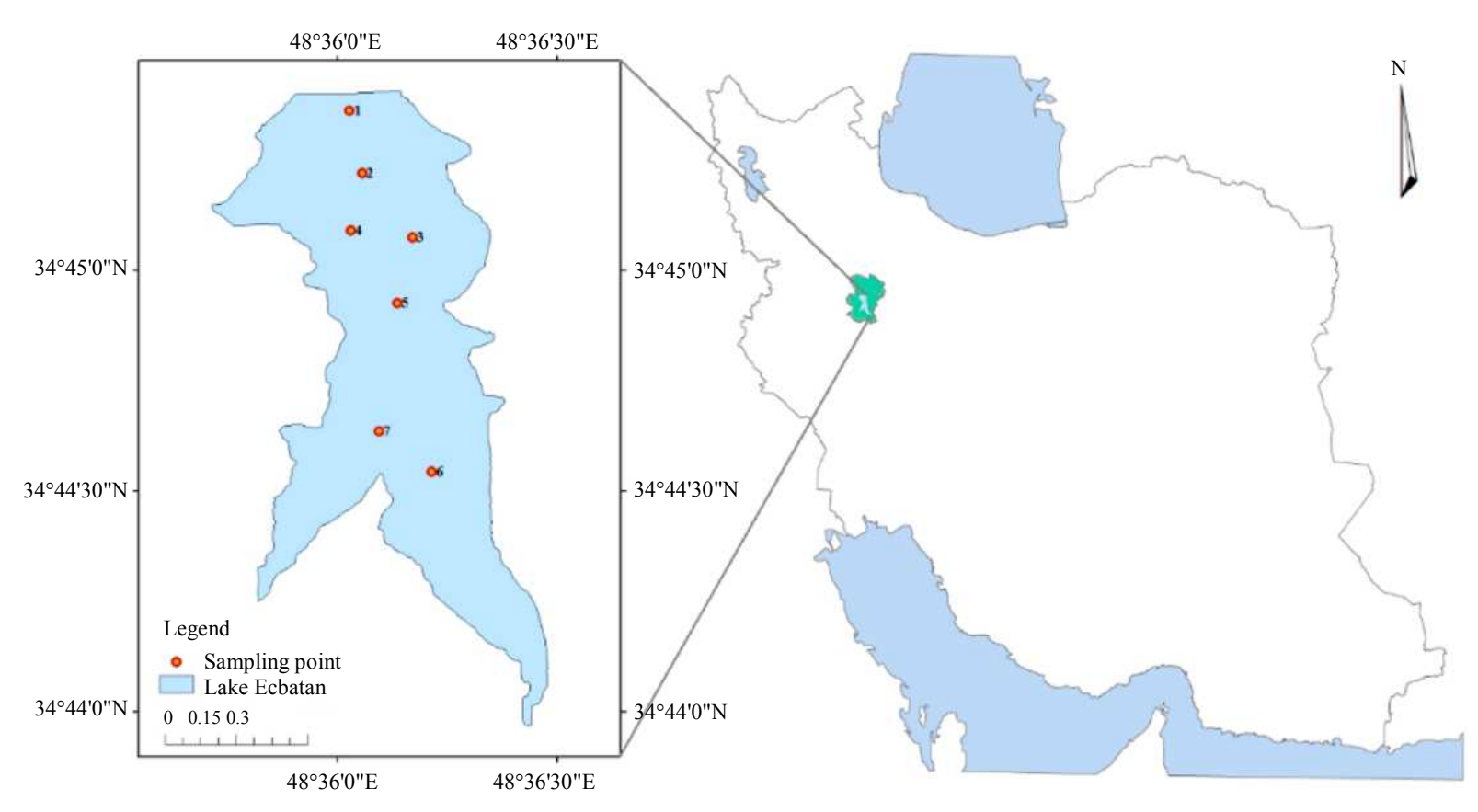

Fig. 1: Ecbatan Dam

\section{Data of the Study}

Field data of the water quality parameters such as chla were collected in 2010 (Weysi et al., 2014). Sampling was accomplished at $30 \mathrm{~cm}$ of water depth. The concentration of chla was estimated using USM method (American Method). In this method first the samples were filtered using filter papers. Then 2-3 mm of Aseton was added to the sample after smashing the filter paper. The volume of solution was increased to 5 $\mathrm{mm}$ with $90 \%$ Aseton and was centrifuged at $500 \mathrm{rpm}$ about 20 minutes. Spectrophotometer was calibrated by 90\% Aseton and optical density was measured at 630 , 647, 664 wavelengths. Equation 1 was used to determine the concentration of chla $(\mathrm{mg} / \mathrm{l})$ :

$$
\text { chla }=11.85(O D 664)-1.54(O D 647)-0.08(O D 630)
$$

Where:

OD664: Denotes the optical density at 664 wavelength OD647: Shows the optical density at 647 wavelength OD630: Is optical density at 630 wavelength

In April, June and September field data (21 chla concentration data) was collected from $30 \mathrm{~cm}$ of water depth. The sampling dates are April, 6, 2010; June, 6, 2010 and December, 5, 2010 respectively. The dates of imagery are also April, 7, 2010; June, 10, 2010 and December, 2, 2010. In this study a time difference of \pm 4 days was between field data and imagery
(Stadelman et al., 2001; Isenstein et al., 2014). Also there were no rain on the lake during this time difference. 15 data were used for calibrating and 6 data were used for verifying the model. Each Landsat 7 imagery covers $185 \times 170 \mathrm{~m}^{2}$ on the earth. The study area locates in one frame of Landsat 7 imagery. Table 1 shows the coordinates of sampling points.

Landsat imagery were downloaded from Science and Observations Center of US Geological Survey Research (USGS (http://earthexplorer.usgs.gov)). Table 2 shows the range of bands one to eight in Landsat 7 imagery. Band six of Landsat 7 is the thermal band of Landsat 7 that is not used in this study.

\section{Pre-Processing of Imagery}

Preprocessing of data is usually done to prepare the data for retrieving different surface parameters such as temperature and reflectance. The type of preprocessing is dependent on the type of data. Each category of data needs a special processing. The majority of these methods for classifying the imagery are: Radiometric, geometric and atmospheric correction.

\section{a- Atmospheric Correction}

Atmospheric correction was accomplished on imagery to remove the effect of water steam, different gases and dust using ENVI 5.1 (Version 5.1Exelis, Inc., McLean, Virginia). Dark subtraction tool and Band Minimum method were used for this purpose. 


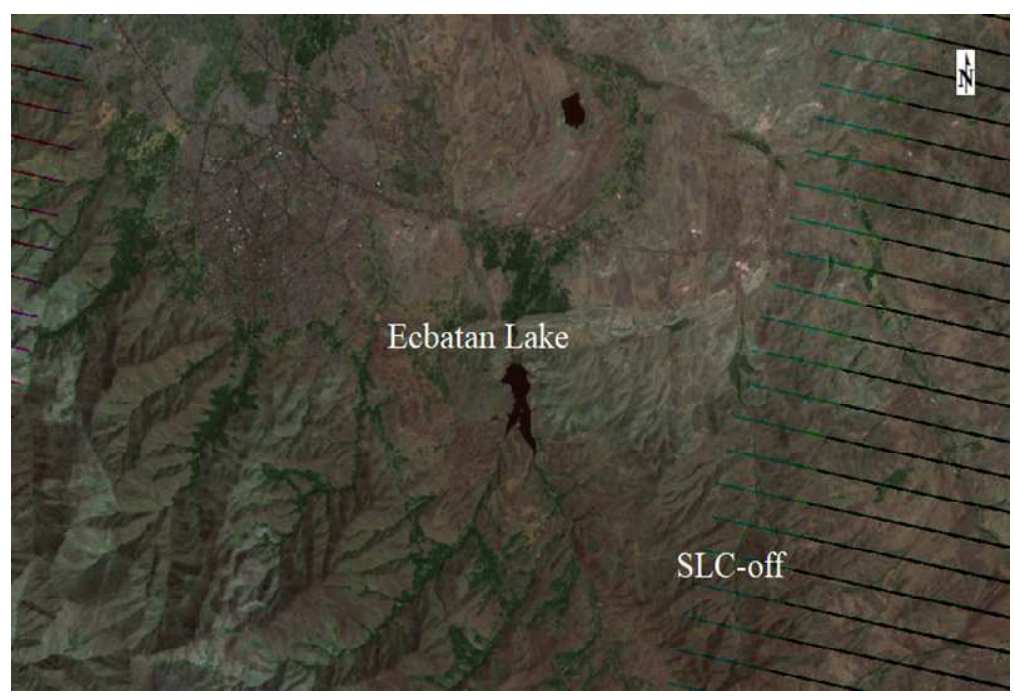

Fig. 2: Landsat 7 image from the study area

Table 1: Coordinates of sampling points

\begin{tabular}{llll}
\hline Station & characteristics & Longitude & latitude \\
\hline 1 & Near the dam & $48^{\circ} 36^{\prime} 1.66^{\prime \prime}$ & $34^{\circ} 45^{\prime} 23.11^{\prime \prime}$ \\
2 & Lake Center & $48^{\circ} 36^{\prime} 3.42^{\prime \prime}$ & $34^{\circ} 45^{\prime} 13.19^{\prime \prime}$ \\
3 & East lake & $48^{\circ} 36^{\prime} 10.27^{\prime \prime}$ & $34^{\circ} 45^{\prime} 4.44^{\prime \prime}$ \\
4 & West lake & $48^{\circ} 36^{\prime} 1.8^{\prime \prime}$ & $34^{\circ} 45^{\prime} 554^{\prime \prime}$ \\
5 & Lake center & $48^{\circ} 36^{\prime} 8.18^{\prime \prime}$ & $34^{\circ} 44^{\prime} 55.52^{\prime \prime}$ \\
6 & Yalfan branch & $48^{\circ} 36^{\prime} 12.90^{\prime \prime}$ & $34^{\circ} 44^{\prime} 32.56^{\prime \prime}$ \\
7 & Abru branch & $48^{\circ} 36^{\prime} 5.66^{\prime \prime}$ & $34^{\circ} 44^{\prime} 38.02^{\prime \prime}$ \\
\hline
\end{tabular}

Table 2: The range of bands1 to 8 of Landsat7 imagery

\begin{tabular}{ll}
\hline Band & Wavelength $(\mu \mathrm{m})$ \\
\hline Band 1-Blue & $0.45-0.52$ \\
Band 2-green & $0.52-0.6$ \\
Band 3-red & $0.63-0.69$ \\
Band 4-near infrared & $0.77-0.9$ \\
Band 5-shortwave near infrared & $1.55-175$ \\
Band 6-Thermal infrared & $10.4-12.5$ \\
Band 7-shortwave near infrared & $2.09-2.35$ \\
Band 8-Panchromatic & $0.52-0.9$ \\
\hline
\end{tabular}

\section{b- Geometric Correction}

In this study G1 products of Landsat 7 were used and geometric and radiometric corrections were applied to them. Since the study area of this research is located in the center of Landsat 7 imagery, there is no SLC-off error for this area. Indeed, SLC-off error is more visible at the edge of the image and this problem disappears at the center of the imagery (Fig. 2).

\section{Results and Discussion}

\section{Implementation}

Processing the imagery was accomplished in ENVI 5.1. Images that contain cloud were omitted from the data. In this study TOA reflectance was used to estimate the concentration of chla. To calculate the net TOA three steps of processing is required:

\section{Calculating the Spectral Radiance}

Equation 2 was used to convert the $\mathrm{Q}_{\text {cal }}$ to spectral radiance $\left(\mathrm{L}_{\lambda}\right)$ for level $\mathrm{G} 1$ products:

$L_{\lambda}=$ Grescale $\times Q_{\text {CAL }}+$ Brescale

Where:

$L_{\lambda} \quad=$ Spectral Radiance at the sensor's aperture in watts/ (meter squared *ster* $\mu \mathrm{m}$ )

Grescale $=$ Rescaled gain (the data product "gain" contained in the Level 1product header or ancillary data record) in watts/ (meter squared $\left.*_{\text {ster* }} \mu \mathrm{m}\right) / \mathrm{DN}$

Brescale $=$ Rescaled bias (the data product "offset" contained in the Level 1product header or ancillary data record) in watts/ (meter squared *ster* $\mu \mathrm{m})$

$Q_{C A L}=$ The quantized calibrated pixel value in $\mathrm{DN}$

Also Equation 2 is written as Equation 3:

$$
\begin{aligned}
& L_{\lambda}=\left(\left(L_{M A X \lambda}-L_{M I N \lambda}\right) /\left(Q_{\text {CALMAX }}-Q_{\text {CALMIN }}\right)\right) \\
& \times\left(Q_{C A L}-Q_{\text {CALMIN }}\right)+L_{\text {MIN } \lambda}
\end{aligned}
$$


Where:

$L_{M I N \lambda}=$ The spectral radiance that is scaled to $Q_{\text {CALMIN }}$ in watts/(meter squared $\times$ ster $\times \mu \mathrm{m})$

$L_{M A X \lambda}=$ The spectral radiance that is scaled to $Q_{C A L M A X}$ in watts/(meter squared $\times$ ster $\times \mu \mathrm{m})$

$Q_{C A L M I N}=$ The minimum quantized calibrated pixel value (corresponding to $L_{M I N \lambda}$ ) in $D N=1$ for LPGS products $=1$ for NLAPS products processed after $4 / 4 / 2004$ and $=0$ for NLAPS products processed before 4/5/2004

$Q_{\text {CALMAX }}=$ The maximum quantized calibrated pixel value (corresponding to $L_{M A X \lambda}$ ) in $\mathrm{DN}=255$ (Landsat 7 Science Data Users Handbook, 2011)

\section{b- TOA Reflectance}

Equation 4 calculates the TOA value:

$$
\rho_{p}=\frac{\pi L_{\lambda} d^{2}}{E S U N_{\lambda} \cos \theta_{s}}
$$

Where:

$\rho_{p} \quad=$ Unitless planetary reflectance

$L_{\lambda} \quad=$ Spectral radiance at the sensor's aperture $d \quad=$ Earth-Sun distance in astronomical units from interpolated from values listed in Table 3

$E S U N_{\lambda}=$ Mean solar exo-atmospheric irradiances from Table 3

$\theta=$ Solar zenith angle in degree

\section{Modeling and Evaluating the Results}

To extract a model for estimating the concentration of chla first the corresponding values of field data for each band were identified. Then the correlation between measured data and their corresponding values from imagery were evaluated for each band. A scatter plot is used to determine the type of correlation between concentration of chla and the value of reflectance at each band. If the shape of scatter plot is curved special functions such as logarithm, exponential or power are used to convert the non- linear relation to a linear relation. In this section the relation between the values of reflectance and concentration of chla were examined. Table 5 shows the amount of correlation $(r)$ between measured concentration of chla and corresponding values from Landsat 7 imagery.

Table 3: Earth-Sun distance

\begin{tabular}{llllll}
\hline Day of Year & 1 & 15 & 32 & 46 & 60 \\
\hline Distance & 0.98331 & 0.98365 & 0.98536 & 0.98774 & 0.99084 \\
Day of Year & 74 & 91 & 106 & 121 & 135 \\
Distance & 0.99446 & 0.99926 & 1.00353 & 1.00756 & 1.01087 \\
Day of Year & 152 & 166 & 182 & 196 & 213 \\
Distance & 1.01403 & 1.01577 & 1.01667 & 1.01646 & 1.01497 \\
Day of Year & 227 & 242 & 258 & 274 & 288 \\
Distance & 1.01281 & 1.00969 & 1.00566 & 1.00119 & 0.99718 \\
Day of Year & 305 & 319 & 335 & 349 & 365 \\
Distance & 0.99253 & 0.98916 & 0.98608 & 0.98426 & 0.98333 \\
\hline
\end{tabular}

Table 4: $\mathrm{ETM}^{+}$Solar Spectral Irradiances

\begin{tabular}{ll}
\hline Band & watts $/($ meter squared* $\mu \mathrm{m})$ \\
\hline 1 & 1997 \\
2 & 1812 \\
3 & 1533 \\
4 & 1039 \\
5 & 230.8 \\
7 & 84.90 \\
8 & 1362 \\
\hline
\end{tabular}

Table 5: Correlation coefficient between measured concentrations of chla and corresponding values from Land sat 7 at each band

\begin{tabular}{ll}
\hline Band & Correlation Coefficient \\
\hline 1 & 0.34 \\
2 & 0.79 \\
3 & 0.67 \\
4 & 0.72 \\
5 & 0.65 \\
6 & 0.68 \\
7 & 0.67 \\
\hline
\end{tabular}




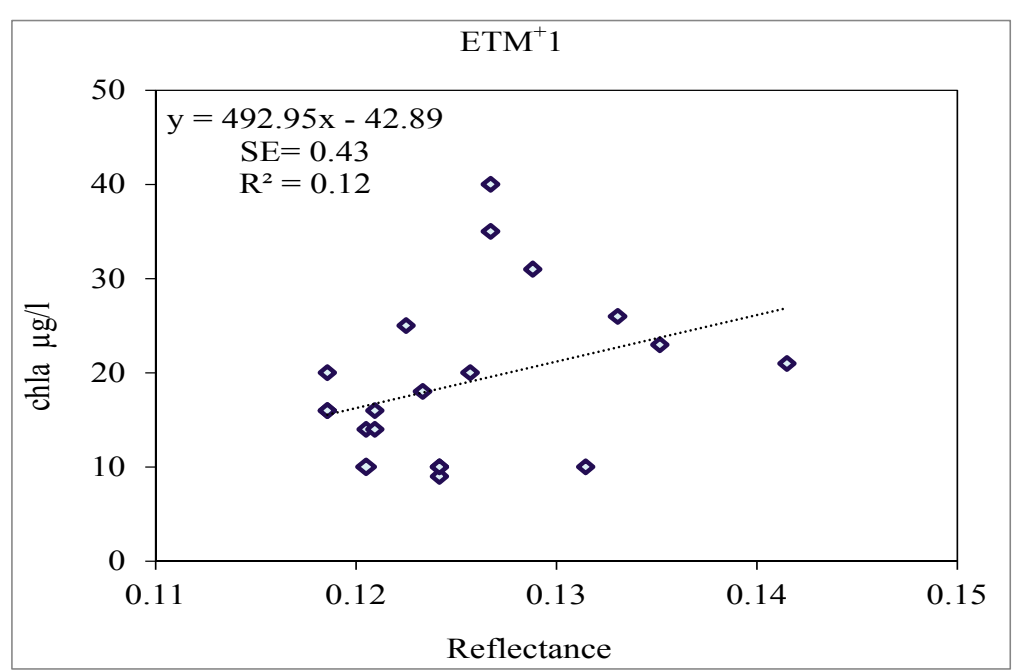

Fig. 3: Scatter plot for concentration of chla and band one

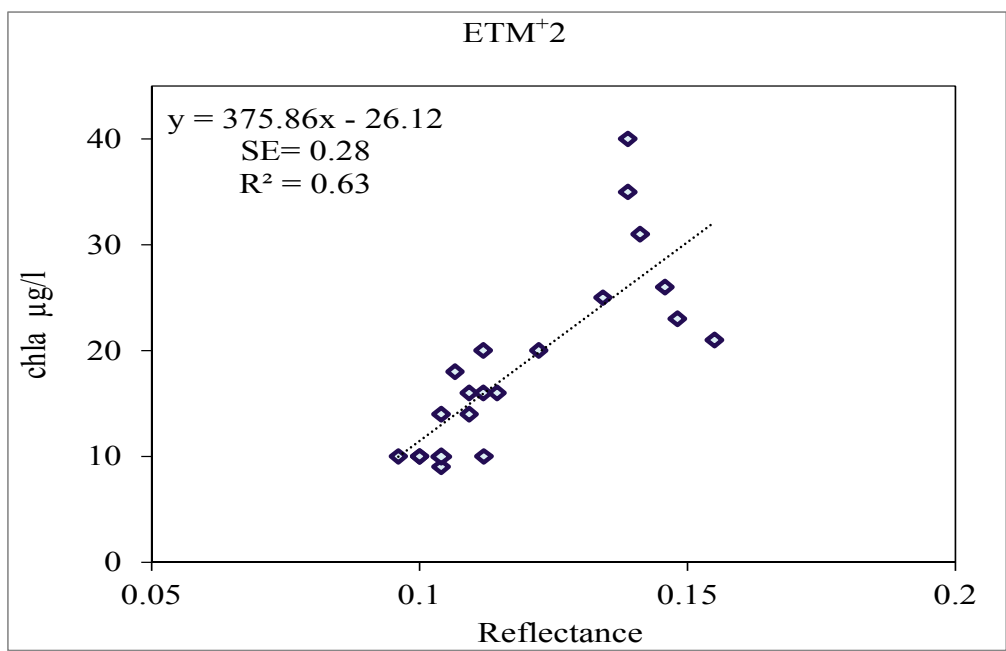

Fig. 4: Scatter plot for concentration of chla and band two

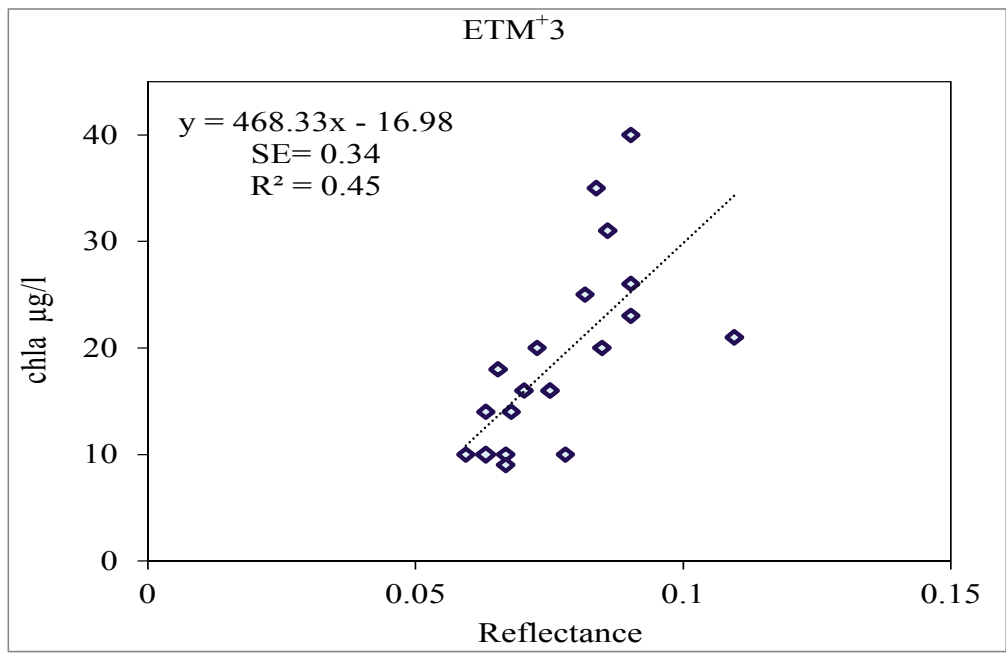

Fig. 5: Scatter plot for concentration of chla and band three 


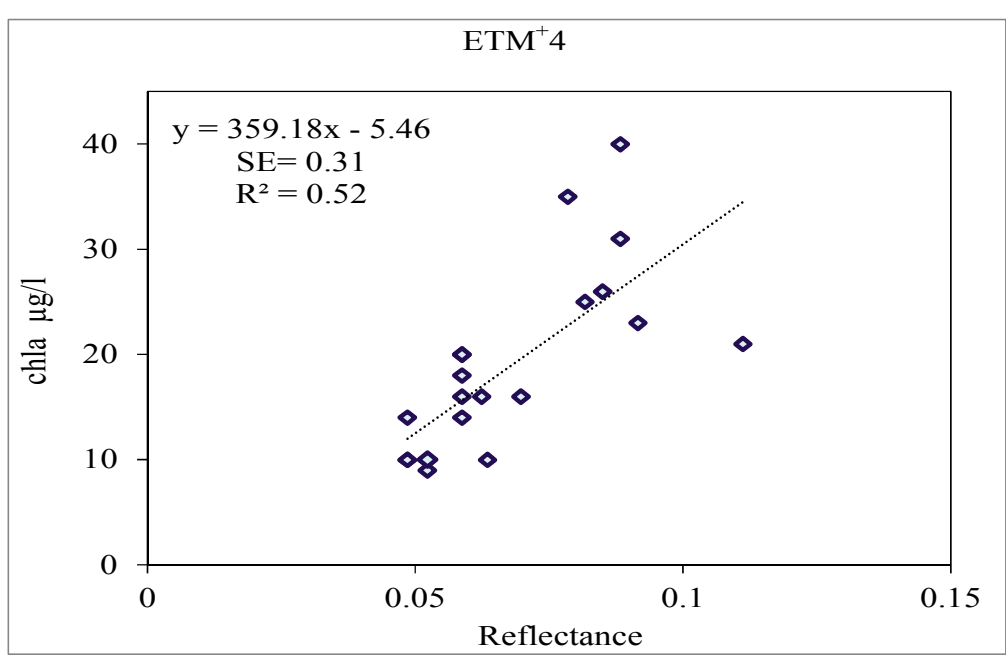

Fig. 6: Scatter plot for concentration of chla and band four

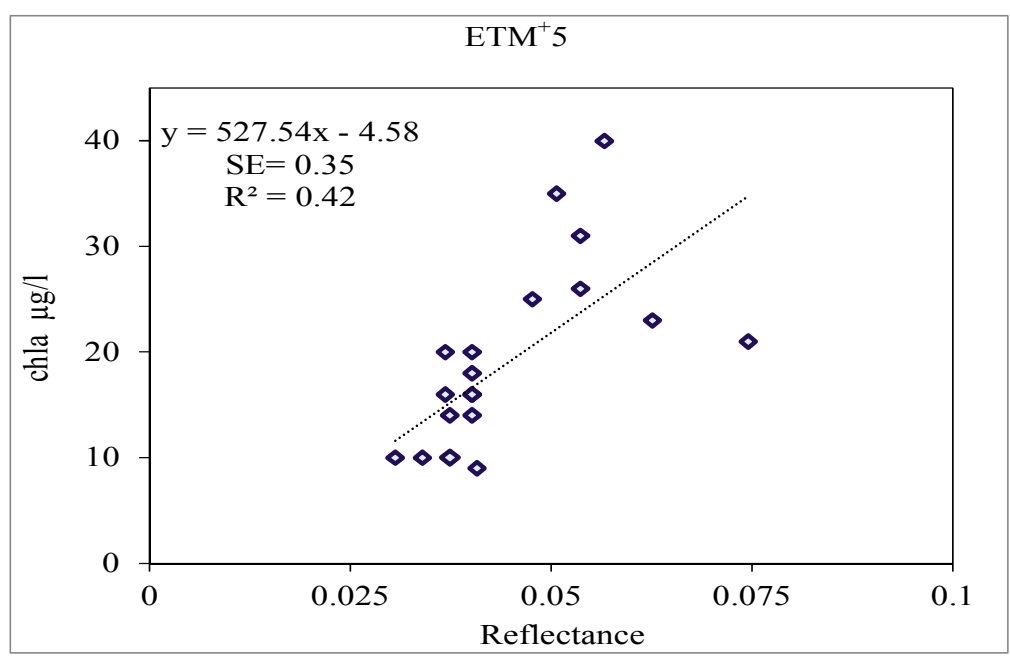

Fig. 7: Scatter plot for concentration of chla and band five

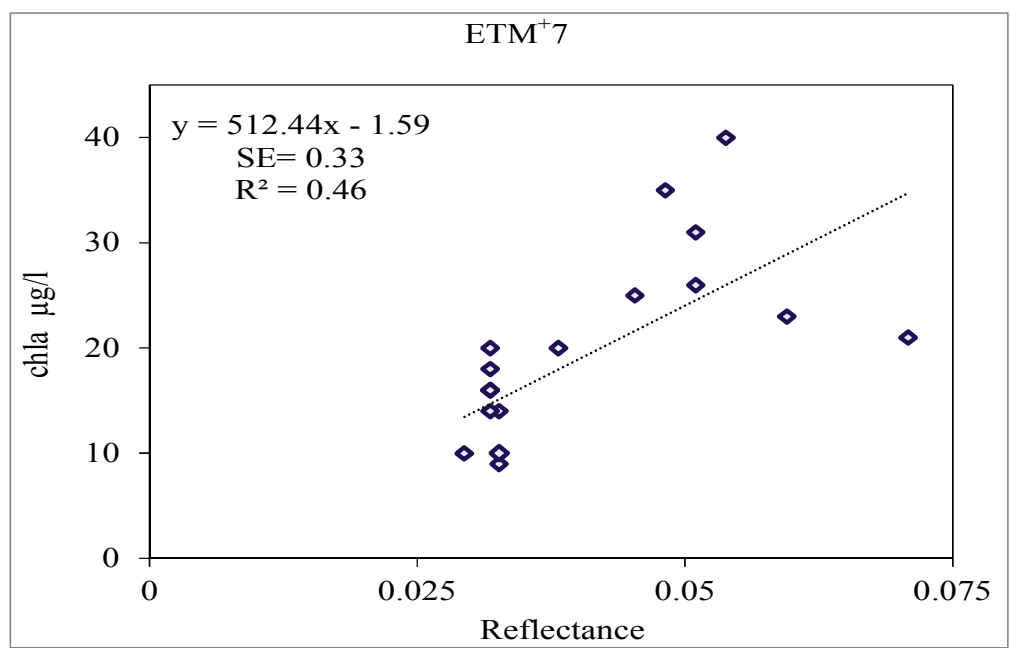

Fig. 8: Scatter plot for concentration of chla and band seven 


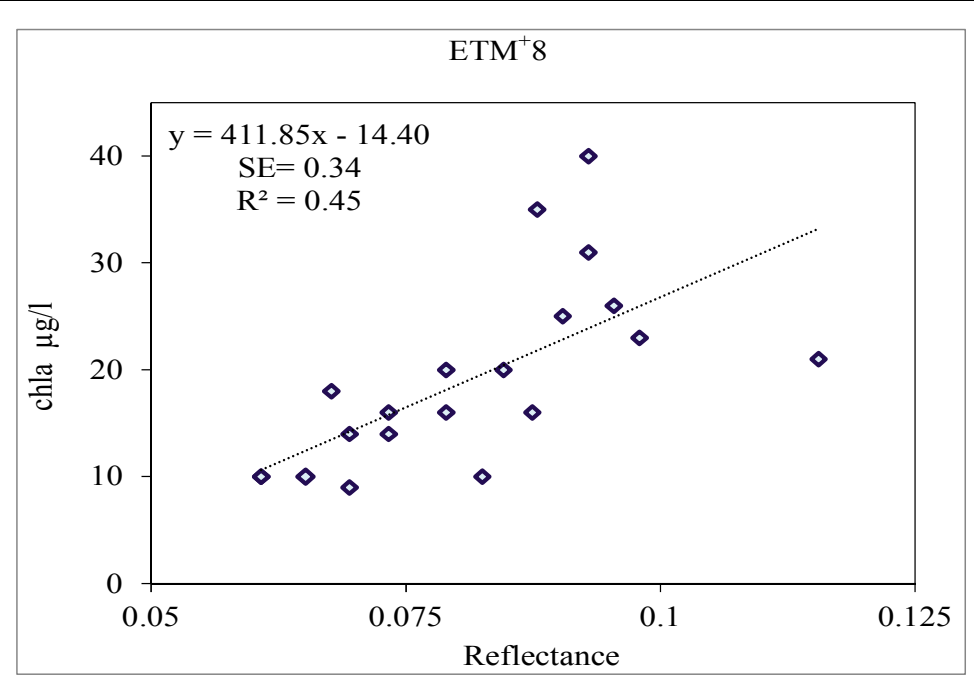

Fig. 9: Scatter plot for concentration of chla and band eight

Based on the results of study the concentration of chla in Ecbatan Lake shows a good correlation with 6 bands of Landsat 7. A linear one band model for the concentration of chla was extracted based on the linear relations between the concentration of chla and corresponding values for each band.

The results of estimating the concentration of chla are presented in Fig. 3-9. The linear relation between observed data and corresponding values at each band are shown as well as $\mathrm{R}^{2}$ and SE value for each model.

Respect to the results shown in these figures, single band models are not convenient for estimating the concentration of chla. Consequently, different conversions and combination of bands are used to extract the relation between chla and reflectance values.

In this section modelling the concentration of chla was accomplished using the relations in Table 6. To reach this aim first a linear model composed of different bands from Landsat 7 was determined to estimate the concentration of chla. Then the conversion of band ratios and band differences were used to examine the relationship between reflectance values and concentration of chla. Also a conversion function was used for bands inspired from NDVI function. This function was made between each two bands and called Normalized Difference Index (NDI).

Modeling the concentration of chla was also done using non- linear functions. Different conversions such as logarithmic, exponential, power, square and sqrt (square root) were used and modeling the concentration of chla was examined. The results are presented in Table 6. Respect to this table the best equation for estimating the concentration of chla is the relation based on band ratios since it has the highest value for $R^{2}$ and the minimum value for SE. Figure 10 shows the results of calibration and verification of this model for estimating the concentration of chla. 2/3 of measured data was used for calibration and $1 / 3$ of the data was used for verification. Table 6 shows the results briefly.
Also in order to evaluate the effect of data with the time difference more than three days on the results, the steps of modeling were repeated after omitting the data of June. Results of this part are shown in Table 7. A comparison between Table 6 and 7 show that although the time difference between field data and imagery has increased one day the accuracy of model has increased. In this study the relationship based on the band ratios was selected as the best model to estimate the concentration of chla.

Equation 5 shows the regression relation based on band ratios. Where chla denotes the concentration of chla and each band has been shown by ETM. The significance of this regression equation was examined. The value of $\mathrm{F}$ was 20.75 that is greater than this value in F Table (2.98) at 5\% of significance. Consequently, the null hypothesis (i.e., no relation between the variables and the concentration of chla) is rejected. Also the amount of $P_{\text {value }}$ is less than 5\% for all variables:

$$
\begin{aligned}
& \text { Chla }=-2261-508\left(\frac{E T M_{2}}{E T M_{1}}\right) \\
& +2443\left(\frac{E T M_{3}}{E T M_{1}}\right)+702\left(\frac{E T M_{4}}{E T M_{3}}\right)+3750\left(\frac{E T M_{5}}{E T M_{1}}\right) \\
& -3956\left(\frac{E T M_{7}}{E T M_{1}}\right) 682\left(\frac{E T M_{7}}{E T M_{2}}\right)+942\left(\frac{E T M_{7}}{E T M_{4}}\right) \\
& +1298\left(\frac{E T M_{7}}{E T M_{5}}\right) 1468\left(\frac{E T M_{8}}{E T M_{1}}\right)+733\left(\frac{E T M_{8}}{E T M_{3}}\right)
\end{aligned}
$$

Some previous studies on different lakes using Landsat images proposed and used band ratios to estimate the concentration of chla. Brezonik et al., (2005) studied 15 lakes in Minnesota using Landsat5. They used a multivariate linear model to estimate the concentration of chla. The model was based on the ratio of blue and red bands and the values of $\mathrm{R}^{2}$ and $\mathrm{SE}$ for 15 data were 0.88 and 0.19 respectively. 
Wang et al. (2006) used green and red bands of Landsat 5 in a linear model to estimate the concentration of chla in Lake Reel foot. 18 data were used in this model and the value of $\mathrm{R}^{2}$ was 0.71 . Alparslan et al. (2007) studied Omerli Dam Lake. They extracted a model to estimate the concentration of chla that used bands one to four of Landsat 7. The values of $\mathrm{R}^{2}$ and SE were 0.49 and 0.58 respectively. They used 49 data in this study.

Table 6: The results of estimating using different multivariate models for Land sat 7 (Three months)

\begin{tabular}{llllll}
\hline Relationship & Used bands & $\mathrm{R}^{2}$ & $\mathrm{R}_{\text {adj }}^{2}$ & $\mathrm{SE}$ & $\mathrm{NRMSE}$ \\
\hline Band Combination & 1,2 & 0.78 & 0.76 & 0.20 & 0.13 \\
Log & $1,2,8$ & 0.80 & 0.76 & 0.20 & 0.12 \\
Exponential & $1,2,8$ & 0.81 & 0.78 & 0.20 & 0.12 \\
SQRT & $1,2,8$ & 0.81 & 0.78 & 0.20 & 0.12 \\
Square & $1,2,8$ & 0.80 & 0.78 & 0.20 & 0.12 \\
Band Ratio & $1,2,3,4,5,7,8$ & 0.95 & 0.91 & 0.20 & 0.04 \\
NDI & $1,2,3,4,5,7,8$ & 0.76 & 0.70 & 0.22 & 0.13 \\
Difference & 1,2 & 0.76 & 0.70 & 0.20 & 0.12 \\
\hline
\end{tabular}

Table 7: The results of estimating using different multivariate models for Land sat 7 (except for June)

\begin{tabular}{llllll}
\hline Relationship & Used bands & $\mathrm{R}^{2}$ & $\mathrm{R}_{\text {adj }}$ & $\mathrm{SE}$ & $\mathrm{NRMSE}$ \\
\hline Band Combination & 2,7 & 0.77 & 0.66 & 0.134 & 0.19 \\
Log & 2,7 & 0.69 & 0.64 & 0.150 & 0.19 \\
Exponential & 2,7 & 0.69 & 0.63 & 0.150 & 0.19 \\
SQRT & 2,7 & 0.69 & 0.63 & 0.133 & 0.19 \\
Square & 2,7 & 0.68 & 0.62 & 0.160 & 0.20 \\
Band Ratio & 1,2 & 0.69 & 0.66 & 0.060 & 0.08 \\
NDI & 2,7 & 0.69 & 0.66 & 0.130 & 0.16 \\
Difference & 1,2 & 0.70 & 0.67 & 0.150 & 0.19 \\
\hline
\end{tabular}

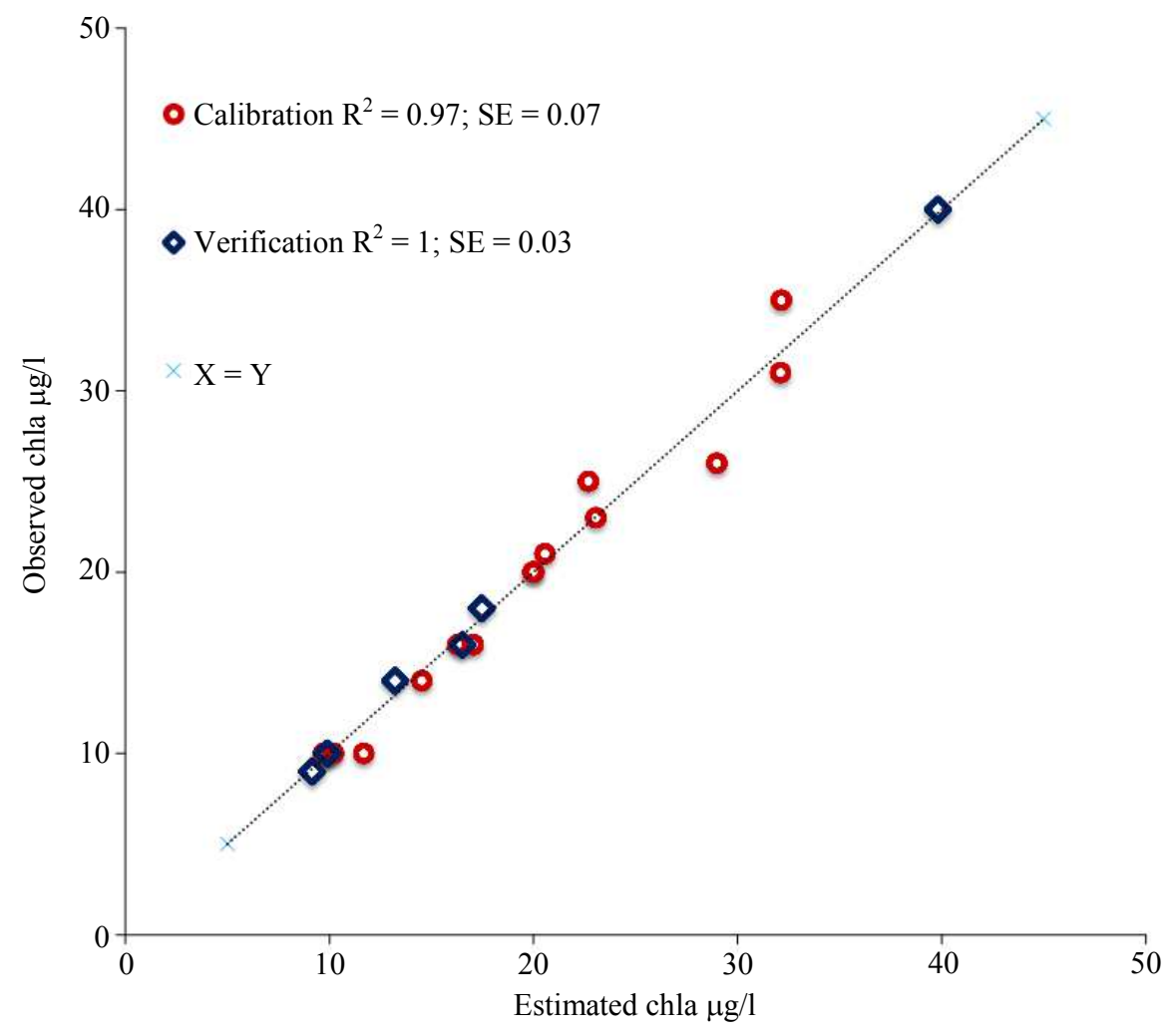

Fig. 10: Calibration and verification of band ratio model 

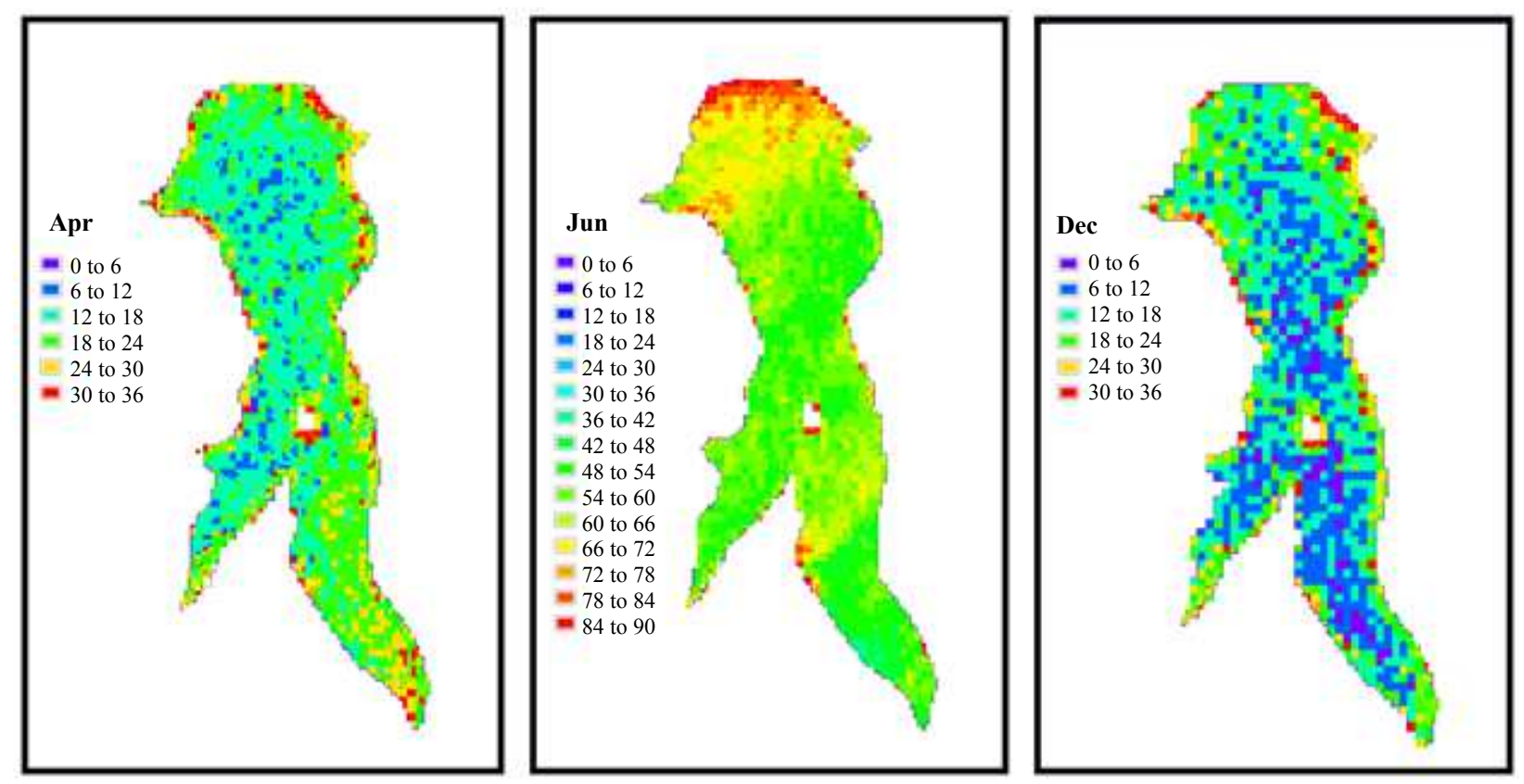

Fig. 11: The comparison of chla distribution over the lake area in April, June and December

Also Chen et al. (2008) studied the Feitsui reservoir using Landsat 7. They extracted a model using bands one to five and seven of Landsat 7. The values of $\mathrm{R}^{2}$ and $\mathrm{SE}$ were 0.68 and 0.1 respectively. They used a multivariate linear model and 24 data for this study. Narteh (2011) investigated Lake Utah in USA. He used a quadratic polynomial equation based on band three to band four ratio of Landsat 7. The value of $\mathrm{R}^{2}$ was 0.93 for this model.

In this study the map of chla variation over the lake was plotted after determining the best model. Figure 11 shows a comparison between the map of chla distribution over the lake in April, June and December. It is clear from Fig. 11 that the amount and distribution of chla over the Lake area is different for each month. Water quality in December is better than April and June in terms of chla concentration. Also the statue of water quality in June has declined. The concentration of chla has increased in the entrance of the Lake and near to the dam structure. This is true for April too. While in December the quality of water in the entrance of the Lake is better than near the dam structure. The best quality of water for three months is in the center of the Lake.

\section{Conclusion}

In this study Landsat 7 imagery was evaluated to extract an empirical relation to estimate the concentration of chla in Ecbatan Lake. First each band was examined using scatter plot to extract a model. In this study the combination of bands and different conversions such as square, sqrt, log, difference, exponential, NDI and band ratios were examined. The relation based on the band ratios showed the best results for estimating the concentration of chla. Respect to $\mathrm{R}^{2}$ adj (0.91) and SE (0.04) this imagery could be used to estimate the concentration of chla.

Also the results of the study showed that in spite of the time difference between field data and imagery, the equation based on the all data of three months shows a better result for all models. Taking into account of some points such as no precipitation during this time difference, using more data helps the results. Besides the results showed that the distribution of chla over the lake surface in each month is very different. This could be due to different hydrologic conditions of the Lake. The concentration of the chla and its distribution over the Lake is affected by the volume of water inside the reservoir too.

\section{Acknowledgment}

We thanks all authors for cooperation in the present study.

\section{Author's Contributions}

Maryam Ghashghaie, Kaveh Ostad-Ali-Askari and Saeid Eslamian designed the study, collected data, wrote the manuscript and revised it.

\section{Ethics}

This study was approved by Bu-Ali Sina University, Hamedan, 6517833131, Iran. 


\section{References}

Alparslan, E., C. Aydöner, V. Tufekci and H. Tüfekci, 2007. Water quality assessment at Ömerli Dam using remote sensing techniques. Environ. Monit. Assess., 135: 391-398. DOI: 10.1007/s10661-007-9658-6

Brezonik, P., K.D. Menken and M. Bauer, 2005. Landsat-based remote sensing of lake water quality characteristics, including chlorophyll and Colored Dissolved Organic Matter (CDOM). Lake Res. Manage., 21: 373-382.

DOI: $10.1080 / 07438140509354442$

Carder, K.L., F.R. Chen, J.P. Cannizzaro, J.W. Campbell and B.G. Mitchell, 2004. Performance of the MODIS semi-analytical ocean color algorithm for chlorophyll-a. Adv. Space Res., 33: 1152-1159. DOI: $10.1016 / \mathrm{S} 0273-1177(03) 00365-\mathrm{X}$

Carvalho, G.D.A., P. Minnett, W. Baringer and V. Banzon, 2007. Detection of Florida "red tides" from SeaWiFS and MODIS imagery. Anais XIII Simpósio Brasileiro de Sensoriamento Remoto, Florianópolis, Brasil.

Chen, L., C.H. Tan, S.J. Kao and T.S. Wang, 2008. Improvement of remote monitoring on water quality in a subtropical reservoir by incorporating grammatical evolution with parallel genetic algorithms into satellite imagery. Water Res., 42: 296-306. DOI: 10.1016/j.watres.2007.07.014

Dall'Olmo, G., A.A. Gitelson, D.C. Rundquist, B. Leavitt and T. Barrow, 2005. Assessing the potential of SeaWiFS and MODIS for estimating chlorophyll concentration in turbid productive waters using red and near-infrared bands. Remote Sens. Environ., 96: 176-187.

DOI: $10.1016 /$ j.rse.2005.02.007

Darecki, M. and D. Stramski, 2004. An evaluation of MODIS and SeaWiFS bio-optical algorithms in the Baltic Sea. Remote Sens. Environ., 89: 326-350. DOI: $10.1016 /$ j.rse.2003.10.012

Gitelson, A.A., D. Gurlin, W.J. Moses and Y.Z. Yacobi, 2011. Remote Estimation of Chlorophyll-a Concentration in Inland, Estuarine and Coastal Waters. In: Advances in Environmental Remote Sensing: Sensors, Algorithms and Applications, CRC Press, pp: 449-478.

Gurlin, D., A.A. Gitelson and W.J. Moses, 2011. Remote estimation of chl-a concentration in turbid productive waters - Return to a simple two-band NIR-red model? Remote Sens. Environ., 115: 3479-3490.

DOI: $10.1016 /$ j.rse.2011.08.011

Estimating and mapping chlorophyll-a concentration in Pensacola Bay, Florida using landsat ETM+ data. Int. J. Remote Sens., 26: 5245-5254.

DOI: $10.1080 / 01431160500219182$
Honeywill, C., D.M. Paterson and S.E. Hegerthey, 2002. Determination of microphytobenthic biomass using pulse-amplitude modulated minimum fluorescence. Eur. J. Phycol., 37: 485-492. DOI: $10.1017 / \mathrm{S} 0967026202003888$

Isenstein, E.M., A. Trescott and M.H. Park, 2014. Multispectral remote sensing of harmful algal blooms in lake champlain, USA. Water Environ. Res., 86: 2271-278. DOI: $10.2175 / 106143014 X 13975035526149$.

Jarvie, H.P., N. Colin and P.J.A. Withers, 2006. Sewageeffluent phosphorus: A greater risk to river eutrophication than agricultural phosphorus? Sci. Total Environ., 360: 246-253. DOI: $10.1016 /$ j.scitotenv.2005.08.038

Jin, X., Q. Xu and C.Z. Huan, 2005. Current status and future tendency of lake eutrophication in China. Sci. China Ser. C, 48: 948-954. DOI: $10.1007 / \mathrm{BF} 03187133$

Kuo, J.T., M.H. Hsieh, W.S. Lung and N. She, 2007. Using artificial neural network for reservoir eutrophication prediction. Ecol. Model., 200: 171-177. DOI: 10.1016/j.ecolmodel.2006.06.018

Lobo, F.L., M.P.F. Costa and E.M.L.M. Novo, 2015. Time-series analysis of Landsat-MSS/TM/OLI images over Amazonian waters impacted by gold mining activities. Remote Sens. Environ., 157: 170-184. DOI: $10.1016 /$ j.rse.2014.04.030

Moses, W.J., A.A. Gitelson, S. Berdnikov and V. Povazhnyy, 2009a. Estimation of chlorophyll-a concentration in case II waters using MODIS and MERIS data-successes and challenges. Environ. Res. Lett.

Moses, W.J., A. Gitelson, S. Berdnikov and V. Povazhnyy, 2009b. Satellite estimation of chlorophyll-a concentration using the red and NIR bands of MERIS-the Azov sea case study. I. Geosci. Remote Sens. Lett., 4: 845-849.

DOI: 10.1109/LGRS.2009.2026657

Narteh, V.N.A., 2011. Mapping and modeling chlorophyll-a concentrations in Utah Lake using landsat 7 ETM+ imagery. MSc Thesis, Brigham Young University.

Norouzi, J., H. Jelokhani and A. Ghasemi, 2011. Investigating and evaluating the quality of potable water in Ekbatan reservoir. Proceedings of the International Conference of Water and Waste Water, (WWW' 11), Tehran, (In Farsi).

Ruddick, K.G., H.J. Gons, M. Rijkeboer and G. Tilstone, 2001. Optical remote sensing of chlorophyll a in case 2 waters by use of an adaptive two-band algorithm with optimal error properties. Applied. Opt., 40: 3575-3585. DOI: 10.1364/AO.40.003575 
Samarghandi, M.R., K. Weysi, A.A. Mehrizi, P. Kaseb and A. Danaee, 2013. Investigating the water quality of ekbatan reservoir using NSFQI. J. North Khorasan Univ. Med. Sci., 5: 63-69.

Schalles, J.F., A.A. Gitelson, Y.Z. Yacobi and A.E. Kroenke, 1998. Estimation of chlorophyll a :form time series measurements of high spectral resolution reflectance in an Eutrophic lake. J. Phycol., 34: 383-390. DOI: 10.1046/j.1529-8817.1998. 340383.x

Smith, V.H., 2003. Eutrophication of freshwater and coastal marine ecosystems a global problem. Environ. Sci. Pollut. Res., 10: 126-139.

DOI: $10.1065 /$ espr2002.12.142

Smith, V.H. and D.W. Schindler, 2009. Eutrophication science: Where do we go from here? Trends Ecol. Evol., 24: 201-207. DOI: 10.1016/j.tree.2008.11.009

Stadelman, T.H., P.L. Brezonik and S. Kloiber, 2001 Seasonal patterns of chlorophyll a and secchi disk transparency in lakes of east-central Minnesota: Implications for design of ground- and satellitebased monitoring programs. Lake Reservoir Manag., 17: 299-314. DOI: 10.1080/07438140109354137

Tayebi, E. and M.R. Saradjian, 2013. Detection and monitoring of algal blooms in Persian Gulf using modis images. Int. Geoinform. Res. Dev. J., 4: 14-20.

Trescott, A., E.M. Isenstein and M.H. Park, 2013. Remote sensing of cyanobacterial blooms in Lake Champlain, USA. Water Sci. Technol. Water Supply, 13: 1402-1409. DOI: 10.2166/ws.2013.114.

Vincent, R.K., X. Qin, R.M.L. McKay, J. Miner and K. Czajkowski, 2004. Phycocyanin detection from LANDSAT TM data for mapping cyanobacterial blooms in Lake Erie. Remote Sens. Environ., 89: 381-392. DOI: 10.1016/j.rse.2003.10.014

Wang, F., L. Han, H.T. Kung and R.B.V. Arsdale, 2006. Applications of Landsat-5 TM imagery in assessing and mapping water quality in Reelfoot Lake, Tennessee. Int. J. Remote Sens., 27: 5269-5283. DOI: $10.1080 / 01431160500191704$
Waxter, M.T., 2014. Analysis of Landsat Satellite Data to Monitor Water Quality Parameters in Tenmile Lake, Oregon. Civil and Environmental Engineering Master's Project Reports, Portland State University.

Weysi, K., H. Nourmoradi, M.R. Samarghandi and M.T. Samadi, 2014. Investigation on the trophic status of Ekbatan Reservoir: A drinking water supply reservoir in Iran. J. Res. Health Sci., 14: 64-68. PMID: 24402853

Wheeler, S.M., L.A. Morrissey, S.N. Levine, G.P. Livingston and W.F. Vincent, 2012. Mapping cyanobacterial blooms in Lake Champlain's Missisquoi Bay using QuickBird and MERIS satellite data. J. Great Lakes Res., 38: 68-75. DOI: 10.1016/j.jglr.2011.06.009.

Yang, W., B. Matsushita, J. Chen, T. Fukushima and R. Ma, 2010. An enhanced three-band index for estimating chlorophyll-a in turbid case-II waters: Case studies of Lake Kasumigaura, Japan and Lake Dianchi, China. I. Geosci. Remote Sens. Lett., 7: 655-659. DOI: 10.1109/LGRS.2010.2044364

Yu, H.B., B.D. Xi, J.Y. Jiang, M.J. Heaphy and H.L. Wang, 2011. Environmental heterogeneity analysis, assessment of trophic state and source identification in Chaohu Lake, China. Environ. Sci. Pollut. Res., 18: 1333-1342. DOI: 10.1007/s11356-011-0490-8

Zhang, F., J. Li, Q. Shen, B. Zhang and C. Wu, 2015. Algorithms and schemes for chlorophyll a estimation by remote sensing and optical classification for turbid lake Taihu, China. I. J. Selected topics applied earth observa. Remote Sens., 8: 350-364. DOI: 10.1109/JSTARS.2014.2333540 